\title{
Vitamin C Loaded Polyethylene: Synthesis and Properties of Precise Polyethylene with Vitamin C Defects via Acyclic Diene Metathesis Polycondensation
}

\author{
Oksana Suraeva, Carole Champanhac, Volker Mailänder, Frederik R. Wurm, Henning Weiss, \\ Rüdiger Berger, Markus Mezger, Katharina Landfester, and Ingo Lieberwirth*
}

Cite This: Macromolecules 2020, 53, 2932-2941

Read Online

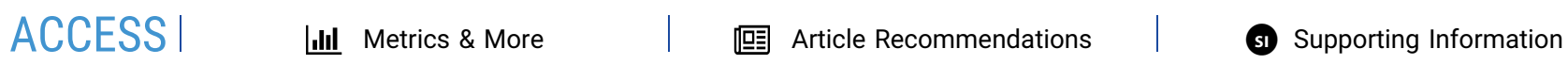

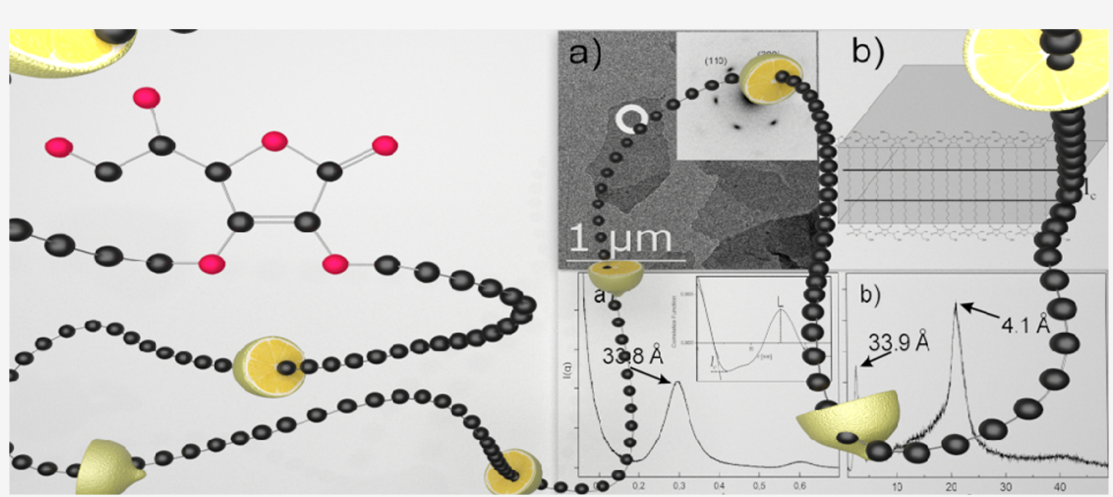

ABSTRACT: A polyethylene-like polymer with an in-chain vitamin $\mathrm{C}$ group was synthesized by olefin metathesis polymerization. Here, we describe both the synthesis and a comprehensive physical characterization. Because of the olefin metathesis synthesis, the vitamin $\mathrm{C}$ groups are equidistantly arranged in the polyethylene (PE) main chain. Their separation was adjusted to $20 \mathrm{CH}_{2}$ units. After hydrogenation, a semicrystalline polymer is obtained that is soluble in polar solvents. Because of its size and steric effect, the vitamin $\mathrm{C}$ acts as a chain defect, which is expelled from the crystal lattice, yielding a lamellar crystal with a homogeneous thickness corresponding to the interdefect distance. The physical properties were examined by various methods including differential scanning calorimetry, X-ray scattering, and transmission electron microscopy. We show that vitamin $\mathrm{C}$ retains its radical scavenger properties despite being incorporated into a polyethylene chain. Furthermore, we demonstrate that it is degrading in alkaline conditions. To complete its suitability as a biocompatible material, cytotoxicity and cell uptake experiments were performed. We show that the polymer is nontoxic and that it is taken up in nanoparticular form via endocytosis processes into the cytoplasm of cells.

\section{INTRODUCTION}

The material class of polymers is characterized, among other things, by the fact that the properties and functionality of the material can be specifically adjusted via the macromolecular architecture. The combination of different molecules by means of polymerization to form a macromolecule, for example, offers an almost innumerable amount of possible new polymers. Thus, it is possible to specifically design a polymer with a certain property or functionality. This can be achieved by transferring the functionality of a specific molecule to the polymer during polymerization. ${ }^{1-3}$

Most fossil and bio-based polymers contain certain defects, such as chain ends, pendant groups, or branches; the latter two are typically randomly distributed along the polymer chain. The random defect distribution makes it difficult to estimate the influence of defects on the properties of the polymer. Of course, this also applies to polymers that contain functional groups. Here, too, the functional groups are randomly distributed in the main chain. Accordingly, a further aspect in the tailor-made design of a polymer with correspondingly planned properties is the positioning of the functional groups in the main chain of the polymer. In contrast to most other polymerizations, acyclic diene metathesis polymerization (ADMET) is characterized by the fact that the functional groups are integrated into the polymer chain at a precisely defined distance. ADMET polymerization is a unique strategy for preparing polymers with precise control over the molecular structure. ${ }^{4}$ It is a step-growth polymerization driven by the release of a condensate, usually ethylene. Furthermore,

Received: January 14, 2020

Revised: March 30, 2020

Published: April 8, 2020 
ADMET offers synthetic routes to perfectly linear polyethylene and to a variety of alkyl branched and functionalized polyethylenes that have precisely placed pendant groups along the hydrocarbon backbone. ${ }^{5-7}$ If the length of the segments and the periodicity of their placement are precisely controlled, crystallization will result in well-defined and predictable morphologies with lamellar polymer crystals of precisely adjusted lamellar thickness. ${ }^{8,9}$ Depending on the size of the defect group, it is either integrated into the crystal lattice or expelled from the crystal to the basal surface of the lamella during crystallization. The first effect is expected for defects smaller than propyl, whereas more bulky defects are expected to be expelled to the surface of the lamellar crystal. The latter allows to generate well-defined structures in which the defect groups are regularly arranged on the surface of a thin, lamellar crystal. As a result, it is possible to control their spatial arrangement simply by crystallization.

Based on the above-mentioned aspects, it should therefore be possible to incorporate a biologically active small molecule into the chain of a polymer. In biological systems, vitamin $\mathrm{C}$ plays the role of an effective antioxidant. ${ }^{10}$ The biochemical functions of vitamin $\mathrm{C}$, especially its antiviral and antitumor properties, are of increasing interest. ${ }^{11}$ However, the use of vitamin $\mathrm{C}$ is limited by its physical and chemical instability. It is highly unstable and very easy to get oxidized and changes to dehydroascorbic acid when exposed to light, air, and elevated temperature.

The introduction of vitamin $\mathrm{C}$ into the polymer structure not only brings functional groups into the obtained product, but it is expected to be bioactive and provides free radical scavenging properties, which can prevent biomolecules such as proteins, DNA, and lipids from damage.

In this work, we synthesize a new polyethylene-mimic polymer with equidistantly distributed vitamin $\mathrm{C}$ groups as a defect in the polymer main chain. Vitamin $C$ presents several electrophilic groups. It contains four hydroxyl groups in positions $2,3,5$, and 6 with different acidities allowing acidbase reactions. The $-\mathrm{OH}$ in position 3 is the more acidic one $\left(\mathrm{p} K_{\mathrm{a}}=4.2\right)$, while the hydroxyl in position 2 has a $\mathrm{p} K_{\mathrm{a}}$ of 11.6 , and those in positions 5 and 6 behave as secondary and primary alcohol $\left(\mathrm{p} K_{\mathrm{a}} \approx 17\right.$ and 16 , respectively). ${ }^{12}$ Initial protection of two hydroxyl groups in positions 5 and 6 is necessary to decrease hydrophilicity of L-ascorbic acid for further modification.

From synthesis, we obtain an amphiphilic, semicrystalline material. Final deprotection reveals hydroxyl groups capable of further modifications. The thermal properties and the crystal structure of the polyethylene-like polymer have been studied as well as the degradation and free-radical scavenging properties. Because of the bio-based synthetic approach and potential biological relevance of the obtained material, we tested the biocompatibility of the polymer by assessing the toxicity of the pure polymer and investigated cellular uptake.

\section{EXPERIMENTAL PART}

Materials. Solvents and all commercially available reagents were purchased from Acros Organics and Sigma-Aldrich and used as received, unless otherwise stated. The first-generation Grubbs catalyst was purchased from Sigma-Aldrich and stored under an argon atmosphere. Deuterated solvents were purchased from Acros Organics and Sigma-Aldrich. All solvents were dried by using molecular sieves for at least $24 \mathrm{~h}$. Chloroform- $d$ was stored over activated $3 \AA$ molecular sieves and anhydrous sodium carbonate to quench residual acid.
Cell lines and buffer: HeLa (human cervix adenocarcinoma (CCL2)) cells were purchased from American Type Culture Collection (ATCC) and maintained in Eagle's Minimum Essential Medium (EMEM). NIH/3T3 (murine fibroblast (CRL-1658)) cells were purchased from ATCC and maintained in Dulbecco's Modified Eagle's Medium (DMEM). All media were supplemented with fetal bovine serum (10\% v/v (Gibco)) and penicillin-streptomycin (100 $\mathrm{UI} / \mathrm{mL}$ (Gibco)). All cells were cultured at $37{ }^{\circ} \mathrm{C}$ in a $5 \% \mathrm{CO}_{2}$ atmosphere. To prevent mutation of the cells, passaging was kept below 30 .

Instrumentation. NMR Spectroscopy. ${ }^{1} \mathrm{H}$ and ${ }^{13} \mathrm{C}\{\mathrm{H}\}$ NMR spectra were acquired on a $300 \mathrm{MHz}$ Bruker system. The temperature was kept at $298.3 \mathrm{~K}$ and calibrated with a standard ${ }^{1} \mathrm{H}$ methanol NMR sample by using a Topspin 3.0 (Bruker). ${ }^{13} \mathrm{C}\{\mathrm{H}\}$ NMR spectra were referenced internally to solvent signals. The ${ }^{13} \mathrm{C}\{\mathrm{H}\}$ NMR (101 $\mathrm{MHz}$ ) measurements were obtained with a ${ }^{1} \mathrm{H}$ powergate decoupling method using $30^{\circ}$ flip angle. All spectra were processed with a MestReNova 12.0.1-20560.

Mass Spectrometry. Mass spectrum acquisitions were conducted on an Advion expression ${ }^{\mathrm{L}}$ compact mass spectrometer (CMS) by using the atmospheric solids analysis probe (ASAP) technique. All spectra were acquired in the positive ion reflectron mode, $\mathrm{m} / z$ range from 10 to $2000 \mathrm{~m} / z$, and acquisition speed $10000 \mathrm{~m} / z$ units s${ }^{-1}$. The obtained spectra were analyzed by using Advion CheMS Express software version 5.1.0.2

Differential Scanning Calorimetry (DSC). Thermal analysis was performed using a Mettler-Toledo DSC 822. For nonisothermal crystallization, the samples were heated well above the melting point and kept at this temperature for $10 \mathrm{~min}$. Unsaturated polymer sample 4 was then cooled at a rate of $10 \mathrm{~K} \mathrm{~min}^{-1}$ to $-140{ }^{\circ} \mathrm{C}$ and heated again at the same rate to $90^{\circ} \mathrm{C}$. Saturated polymer sample 6 was then cooled at a rate of $10 \mathrm{~K} \mathrm{~min}^{-1}$ to $0{ }^{\circ} \mathrm{C}$ and heated again at the same rate to $120{ }^{\circ} \mathrm{C}$. The second run melting curve was used for determining the melting enthalpy $\left(\Delta H_{\mathrm{m}}\right)$ and $T_{\mathrm{m}}$.

$X$-ray Diffraction. Wide-angle X-ray diffraction (WAXD) patterns of the precision PEs were obtained on a Philips PW 1820 diffractometer (scattering angle $2^{\circ} \leq 2 \theta \leq 60^{\circ}, 0.02^{\circ}$ step size) using $\mathrm{Cu} \mathrm{K} \alpha$ radiation $(\lambda=1.5418 \AA)$ as the $\mathrm{X}$-ray source. The crystallinity $\left(X_{\mathrm{c}}^{\mathrm{WAXD}}\right)$ of PEs with pseudohexagonal crystal phase was determined from the WAXD patterns as

$$
X_{\mathrm{c}}^{\mathrm{WAXD}}=\frac{A_{\mathrm{c}}}{A_{\mathrm{c}}+A_{\mathrm{a}}}
$$

where $A_{c}$ refers to the integrated area of the Bragg reflections from the PE crystal and $A_{\mathrm{a}}$ to the amorphous halo. The corresponding bulk volume fraction crystallinity $X_{\mathrm{vol}}$ can be calculated from $X_{\mathrm{c}}^{\mathrm{WAXD}}$ :

$$
X_{\mathrm{vol}}=\frac{\rho_{\mathrm{a}}}{\rho_{\mathrm{c}} / X_{\mathrm{c}}^{\mathrm{WAXD}}-\rho_{\mathrm{c}}+\rho_{\mathrm{a}}}
$$

where $\rho_{\mathrm{c}}$ and $\rho_{\mathrm{a}}$ are the densities of the crystalline and amorphous phases. The amorphous phase also contains vitamin $\mathrm{C}$ molecules. But since in this case the density $\rho_{\mathrm{a}}$ is not known, we assume the values for $\operatorname{PE}\left(\rho_{\mathrm{c}}=1.000 \mathrm{~g} \mathrm{~cm}^{-3}\right.$ and $\left.\rho_{\mathrm{a}}=0.855 \mathrm{~g} \mathrm{~cm}^{-3}\right) .^{13}$

Small-angle X-ray scattering (SAXS) data were measured at room temperature in transmission geometry on a free-standing polymer foil (Rigaku MicroMax 007 X-ray generator with $\mathrm{Cu}$ anode, Osmic Confocal Max-Flux curved multilayer optics, $\lambda=0.154 \mathrm{~nm}$ ). Scattered intensities were recorded on an online image plate detector (Mar345, MarResearch) at a sample-detector distance of $2.2 \mathrm{~m}$ calibrated with silver behenate. Background noise was removed by a Laplace filter based masking algorithm. The scattering pattern $I(q)$ vs momentum transfer $q=4 \pi / \lambda \sin (\theta)$ was obtained by radial averaging of the $2 \mathrm{D}$ scattering patterns. The long period $L^{\mathrm{SAXS}}$ can be estimated from the position $q_{0}$ of the scattering maxima in the SAXS patterns:

$$
L^{\mathrm{SAXS}}=2 \pi / q_{0}
$$


The lamellar crystal thickness $\left(l_{c}\right)$ can then be calculated from the long period $L^{\text {SAXS }}$ and bulk volume fraction crystallinity $X_{\text {vol }}$ based on the equation

$$
l_{\mathrm{c}}=L^{\mathrm{SAXS}} \times X_{\mathrm{vol}}
$$

To extract additional structural data, the pair correlation function was calculated from the Lorentz-corrected SAXS patterns by using the SAXSDAT software. ${ }^{14}$

Thermal Gravimetric Analysis (TGA). TGA was measured on a Mettler Toledo ThermoSTAR TGA/SDTA 851-Thermowaage in a nitrogen atmosphere. The heating rate was $10^{\circ} \mathrm{C} \mathrm{min}^{-1}$ in a temperature range between 25 and $900{ }^{\circ} \mathrm{C}$. Gel-permeation chromatography (GPC) measurements were performed in THF at a sample concentration of $1 \mathrm{~g} \mathrm{~L}^{-1}$. Sample injection was performed by a 717 plus autosampler (Waters) at $30^{\circ} \mathrm{C}$. The flow was $1 \mathrm{~mL} \mathrm{~min}^{-1}$. Three SDV columns (PSS) with the dimensions $300 \times 80 \mathrm{~mm}^{2}, 10$ $\mu \mathrm{m}$ particle size, and pore sizes of 106,104 , and $500 \AA$ were employed. Detection was accomplished with a DRI Shodex RI-101 detector (ERC) and a UV-vis S-3702 detector (Soma). Calibration was performed using polystyrene standards provided by Polymer Standards Service.

Transmission Electron Microscopy (TEM). A FEI Tecnai F20 transmission electron microscope operated at an acceleration voltage of $200 \mathrm{kV}$ was used to determine the crystal morphology, thickness, and crystal structure. Bright field (BF), parallel beam nanoelectron diffraction (NBED), and energy-filtered transmission electron microscopy (EFTEM) ${ }^{15}$ were used for measurements. To study the crystallization behavior, hydrogenated polymer $\mathbf{6}$ was dissolved in hot ethyl acetate and crystallized slowly during cooling from solution or dissolved in tetrahydrofuran (THF) and crystallized by adding dropwise deionized water while gently stirring.

Radical Scavenging Test. The radical scavenging ability of the conducting polymers, and their monomers, is assessed through their reaction with stable $\alpha, \alpha$-diphenyl- $\beta$-picrylhydrazyl (DPPH) radicals. Radical scavenging activities were assessed on the basis of the capacity of the compounds to scavenge the stable DPPH free radical by using the methodology of Brand-Williams et al. ${ }^{16} \mathrm{DPPH}$ typically extracts a proton to form DPPHH during the reaction. Polymer solution $(5 \mathrm{mg}$ in $0.1 \mathrm{~mL}$ of THF) was added to $3.9 \mathrm{~mL}$ of $6 \times 10^{-5} \mathrm{M} \mathrm{DPPH}$ free radical in THF, vortexed, and left to stand for $30 \mathrm{~min}$ at room temperature.

Atomic Force Microscopy (AFM). To measure the lamellar thickness, AFM measurements were performed (Bruker, Dimension Icon, operated in peak force mode) using OLTESPA probes (nominal spring constant $2 \mathrm{~N} / \mathrm{m}$ ) in ambient conditions. The samples were prepared by dropping $5 \mu \mathrm{L}$ of the dispersion containing the solution grown crystals onto a freshly cleaved mica substrate. Then the excess liquid was blotted off with the edge of a filter paper.

Quantification of the Cellular Uptake by Flow Cytometry. The cells were seeded as a triplicate in 24-well plates 1 day before the experiment. The nanocrystals $\left(13.3 \mu \mathrm{L}\right.$ at $\left.1.4 \mathrm{~g} \mathrm{~L}^{-1}\right)$ were dispersed in a medium without serum, or a medium with $10 \%$ fetal bovine serum, or a medium with $10 \%$ human serum to a final concentration of $25 \mu \mathrm{g}$ $\mathrm{mL}^{-1}$. The cells were washed, and $1.0 \mathrm{~mL}$ of the fluorescently labeled nanocrystal dispersion was added to the cells and incubated for $4 \mathrm{~h}$ at $37^{\circ} \mathrm{C}$ in a $5 \% \mathrm{CO}_{2}$ atmosphere. Then, the supernatant was removed, and the cells were washed three times with PBS. They were recovered with a $1 \mathrm{X}$ trypsin solution and washed with PBS. They were then incubated for $20 \mathrm{~min}$ at RT with Zombie Aqua (according to the manufacturer's recommendation). The cells were washed with PBS and suspended in $500 \mu \mathrm{L}$ of PBS before analysis. Twenty thousand events were recorded on an Attune NxT flow cytometer using three lasers (violet $\left(\lambda_{\text {exc }}: 405 \mathrm{~nm} / \lambda_{\text {em }}: 440 \mathrm{~nm}\right)$, blue $\left(\lambda_{\text {exc }}: 488 \mathrm{~nm} / \lambda_{\text {em }}\right.$ : $590 \mathrm{~nm})$, and red $\left.\left(\lambda_{\text {exc }}: 638 \mathrm{~nm} / \lambda_{\text {em }}: 670 \mathrm{~nm}\right)\right)$. The dead cells were excluded from the cell population based on their Zombie Aqua staining. Each sample was tested at least twice to ensure the reproducibility of the experiment.

Verification of the Cellular Uptake by Confocal Laser Scanning Microscopy. The cells were seeded in 8-well Ibidi dishes 1 day before the experiment. The nanocrystals were dispersed in a medium without serum, or a medium with $10 \%$ fetal bovine serum, or a medium with $10 \%$ human serum to a final concentration of $12.5 \mu \mathrm{g} \mathrm{mL}^{-1}$. The cells were washed, and $250 \mu \mathrm{L}$ of the nanocrystal solution was added to the cells and incubated for $4 \mathrm{~h}$ at $37^{\circ} \mathrm{C}$ in a $5 \% \mathrm{CO}_{2}$ atmosphere. Then, the supernatant was removed, and the cells were washed three times with PBS. Next, the cell membrane was stained with a Cell Mask Deep Red solution or a Cell Mask Green for $5 \mathrm{~min}$ at room temperature (RT). The cells were washed once before imaging. Depending on the dye combination applied for staining, two channels were set up: an argon laser was used to detect the Cell Mask Green $\left(\lambda_{\text {exc }}: 488 \mathrm{~nm} / \lambda_{\text {em }}: 520-560 \mathrm{~nm}\right)$, a DPSS diode was used to detect the CY3 dye $\left(\lambda_{\text {exc }}: 561 \mathrm{~nm} / \lambda_{\text {em }}: 580-620 \mathrm{~nm}\right)$, and a HeNe laser was used for the Cy5 dye or the Cell Mask Deep Red staining ( $\lambda_{\text {exc }}: 633$ $\left.\mathrm{nm} / \lambda_{\text {em }}: 660-680 \mathrm{~nm}\right)$. The images were acquired by using the $63 \times$ oil objective of a Leica LSM5 instrument.

Cell Viability Assay. Cytotoxicity was determined by using the CellTiter 96 Aqueous One Solution Cell Proliferation Assay (Promega), following the procedure recommended by the manufacturer. ${ }^{17} \mathrm{HeLa}$ and NIH/3T3 cells were seeded in triplicate on a 96well plate and grown overnight in $120 \mu \mathrm{L}$ of complete media. The next day, $100 \mu \mathrm{L}$ of media solution was removed. The cells were incubated with $100 \mu \mathrm{L}$ solutions of 50, 25, 12.5, 6.25, and $3.125 \mu \mathrm{g}$ $\mathrm{L}^{-1}$ pure polymer (VC06) nanocrystals in complete DMEM medium for $24 \mathrm{~h}$ at $37^{\circ} \mathrm{C}$. After removal of the media, MTS reagent $(20 \mu \mathrm{L})$ diluted in $100 \mu \mathrm{L}$ of media was added and incubated for $2 \mathrm{~h}$. The absorbance $(490 \mathrm{~nm})$ was recorded by a plate reader, and the viability was determined as described by the manufacturer.

Synthesis. Synthesis of 5,6-O-Ispropylidene-L-ascorbic Acid (2). 5,. 6-O-Isopropylidene-L-ascorbic acid (2) was prepared according to a previously published procedure. ${ }^{18}{ }^{1} \mathrm{H} \mathrm{NMR}\left(\mathrm{CDCl}_{3}, \delta\right): 4.69(\mathrm{~s}$, $\left.1 \mathrm{H}, \mathrm{OCH}_{2} \mathrm{CHOCH}\right), 4.24\left(\mathrm{~m}, 1 \mathrm{H}, \mathrm{OCH}_{2} \mathrm{CHOCH}\right), 4.09(\mathrm{~m}, 1 \mathrm{H}$, $\left.\mathrm{OCH}_{2} \mathrm{CHOCH}\right), 3.88\left(\mathrm{~m}, 1 \mathrm{H}, \mathrm{OCH}_{2} \mathrm{CHOCH}\right), 1.25(\mathrm{~s}, 6 \mathrm{H}$, $\mathrm{CCH}_{3}$ ).

Synthesis of 10-(Dec-9-en-1-yloxy)-5-(2,2-dimethyl-1,3-dioxolan-4-yl)-3-(pent-4-en-1-yloxy)furan-2(5H)-one (3). 5,6-Isopropylidene-L-ascorbic acid (2) (2.00 g, $9.0 \mathrm{mmol}, 1.0$ equiv) and $\mathrm{K}_{2} \mathrm{CO}_{3}$ ( $3.18 \mathrm{~g}, 23.0 \mathrm{mmol}, 2.5$ equiv) were dissolved in $34 \mathrm{~mL}$ of a DMSO/ THF (9:8) mixture. The reaction mixture was stirred for $10 \mathrm{~min}$ at room temperature, and 11-bromo-1-undecene $(5.05 \mathrm{~mL}, 23.0 \mathrm{mmol}$, 2.5 equiv) was dissolved in $17 \mathrm{~mL}$ of DMSO/THF (9:8) and added dropwise to this mixture before left to stir at RT for $4 \mathrm{~h}$. The reaction mixture diluted with water and extracted with ethyl acetate. The organic layer was thoroughly washed with water, and combined organic phases were dried over anhydrous $\mathrm{Na}_{2} \mathrm{SO}_{4}$; the solvents were removed under reduced pressure. The product was purified by column chromatography over silica gel eluting with ethyl acetate/ hexane $(1: 4)$ to give 3 as pale yellow oil. Yield: $70 \% .{ }^{1} \mathrm{H}$ NMR $\left(\mathrm{CDCl}_{3}, \delta\right): 5.73\left(\mathrm{~m}, 2 \mathrm{H}, \mathrm{C} \underline{\mathrm{H}}=\mathrm{CH}_{2}\right), 4.88\left(\mathrm{~m}, 4 \mathrm{H}, \mathrm{CH}=\mathrm{CH}_{2}\right), 4.42$ (s, $\left.1 \mathrm{H}, \mathrm{OCH}_{2} \mathrm{CHCHO}\right), 4.36\left(\mathrm{~m}, 2 \mathrm{H}, \mathrm{OCH}_{2} \mathrm{CHCHO}\right), 4.18(\mathrm{~m}$, $\left.1 \mathrm{H}, \mathrm{OCH}_{2} \mathrm{CHOCH}\right), 4.04\left(\mathrm{~m}, 2 \mathrm{H}, \mathrm{OCH}_{2} \mathrm{CH}_{2} \mathrm{CH}_{2}\right), 3.96(\mathrm{~m}, 2 \mathrm{H}$, $\left.\mathrm{OCH}_{2} \mathrm{CH}_{2} \mathrm{CH}_{2}\right), 1.96\left(\mathrm{~m}, 4 \mathrm{H}, \mathrm{CH}_{2} \mathrm{CH}_{2} \mathrm{CHCH}_{2}\right), 1.63$ (m, 4H, $\left.\mathrm{OCH}_{2} \mathrm{CH}_{2} \mathrm{CH}_{2}\right), 1.33\left(\mathrm{~s}, 3 \mathrm{H}, \mathrm{CCH}_{3}\right), 1.29\left(\mathrm{~s}, 3 \mathrm{H}, \mathrm{CCH}_{3}\right), 1.22$ (br s, $20 \mathrm{H}) .{ }^{13} \mathrm{C}$ NMR $\left(\mathrm{CDCl}_{3}, \delta\right): 169.3(\mathrm{O}-\mathrm{C}-\underline{\mathrm{C}}=\mathrm{O}), 156.0(\mathrm{O}-\mathrm{CH}-$ $\mathrm{CH}-\underline{\mathrm{C}}-\mathrm{O}), 139.2\left(\mathrm{CH}_{2}=\underline{\mathrm{CH}}-\mathrm{CH}_{2}-\right), 121.9(\mathrm{O}-\underline{\mathrm{C}}-\mathrm{C}=\mathrm{O}), 114.2$ $\left(\mathrm{CH}_{2}=\mathrm{CH}-\mathrm{CH}_{2}-\right), \quad 110.2\left(\mathrm{CH}_{3}-\underline{\mathrm{C}}-\mathrm{O}-\mathrm{CH}_{2}\right), 74.7(\mathrm{O}-\mathrm{CH}-$ $\mathrm{CH}-\mathrm{C}-\mathrm{O}), 74.2(\mathrm{O}-\mathrm{CH}-\underline{\mathrm{C}} \mathrm{H}-\mathrm{C}-\mathrm{O}), 72.6,72.2\left(\mathrm{C}-\mathrm{O}-\underline{\mathrm{CH}}_{2}-\right.$ $\left.\mathrm{CH}_{2}\right), 65.3\left(\mathrm{O}-\mathrm{CH}_{2}-\mathrm{CH}-\mathrm{O}\right), 33.8\left(\mathrm{CH}_{2}=\mathrm{CH}-\mathrm{CH}_{2}-\right), 29.8$, 29.5, 29.1, 28.9 (backbone, $\left.-\underline{\mathrm{CH}}_{2}-\right), 25.9,25.8,25.6,25.5\left(\mathrm{CH}_{3}-\right)$. CMS (EI): calcd for $\mathrm{C}_{19} \mathrm{H}_{28} \mathrm{O}_{6}: 521.0(\mathrm{M}+)$; found: $521.5(\mathrm{M}+) . \mathrm{m} /$ $e: 537.4,524.5,523.5,522.5,521.5,519.4,505.4,464.4,463.4$, and 420.4 .

Representative Procedure for ADMET Bulk Polycondensation (4). 3 ( $0.55 \mathrm{~g}, 1.40 \mathrm{mmol}, 1$ equiv) was charged into a flame-dried $25 \mathrm{~mL}$ flask in $\mathrm{CH}_{2} \mathrm{Cl}_{2}(2 \mathrm{~mL})$, and the solution was stirred for $5 \mathrm{~min}$ at room temperature under nitrogen; first-generation Grubbs catalyst ( 0.01 equiv) was then added to this solution under a nitrogen atmosphere. After the addition of the catalyst, the reaction mixture was stirred at room temperature under nitrogen flow and then exposed to an intermittent vacuum to remove ethylene and remaining solvent. After that, the polymerization temperature was increased and 
Scheme 1. Synthetic Procedure for $\alpha, \omega$-Diene Functionalized L-Ascorbic Acid 3 and Its ADMET Polymerization
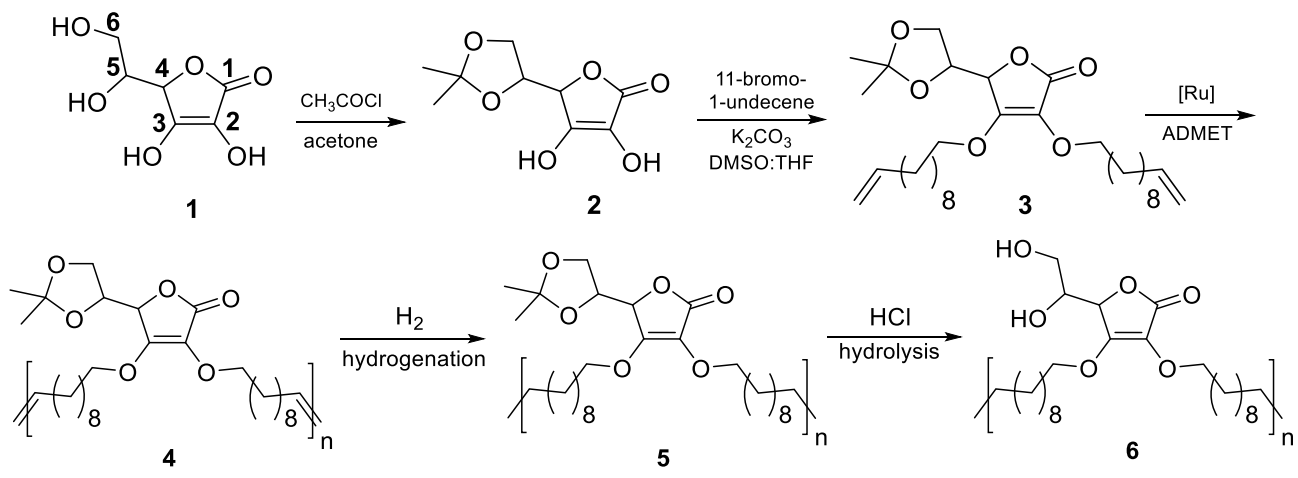

kept at predetermined temperatures $\left(40,60\right.$, and $\left.80{ }^{\circ} \mathrm{C}\right)$ with different time intervals until the magnetic stirrer stopped due to the high viscosity. The reaction mixture was cooled to room temperature, and the catalyst was quenched by adding ethyl vinyl ether $(1 \mathrm{~mL}$ in 2 $\mathrm{mL}$ of $\mathrm{CH}_{2} \mathrm{Cl}_{2}$ ), followed by $30 \mathrm{~min}$ stirring at room temperature. The reaction mixture was precipitated in methanol $(100 \mathrm{~mL})$ and decanted. Brown solid polymers were obtained after removal of the solvent. ${ }^{1} \mathrm{H}$ NMR $\left(\mathrm{CDCl}_{3}, \delta\right): 5.31-5.26(\mathrm{~m}, 2 \mathrm{H}, \mathrm{C} \underline{\mathrm{H}}=\mathrm{C} \underline{\mathrm{H}}), 4.42(\mathrm{~s}$, $\left.1 \mathrm{H}, \mathrm{OCH}_{2} \mathrm{CHCHO}\right), 4.36\left(\mathrm{~m}, 2 \mathrm{H}, \mathrm{OC}_{2} \mathrm{CHCHO}\right), 4.18(\mathrm{~m}, 1 \mathrm{H}$, $\left.\mathrm{OCH}_{2} \mathrm{CHOCH}\right), 4.04\left(\mathrm{~m}, 2 \mathrm{H}, \mathrm{OCH}_{2} \mathrm{CH}_{2} \mathrm{CH}_{2}\right), 3.96(\mathrm{~m}, 2 \mathrm{H}$, $\left.\mathrm{OCH}_{2} \mathrm{CH}_{2} \mathrm{CH}_{2}\right), 1.96\left(\mathrm{~m}, 4 \mathrm{H}, \mathrm{CH}_{2} \mathrm{CH}_{2} \mathrm{CHCH}_{2}\right), 1.63(\mathrm{~m}, 4 \mathrm{H}$, $\left.\mathrm{OCH}_{2} \mathrm{CH}_{2} \mathrm{CH}_{2}\right), 1.33\left(\mathrm{~s}, 3 \mathrm{H}, \mathrm{CCH}_{3}\right), 1.29$ (s, $\left.3 \mathrm{H}, \mathrm{CCH}_{3}\right), 1.22$ (br s, $24 \mathrm{H}) .{ }^{13} \mathrm{C}$ NMR $\left(\mathrm{CDCl}_{3}, \delta\right): 165.6(\mathrm{O}-\mathrm{C}-\underline{\mathrm{C}}=\mathrm{O}), 156.0(\mathrm{O}-\mathrm{CH}-$ $\mathrm{CH}-\underline{\mathrm{C}}-\mathrm{O}), 130.3(\underline{\mathrm{C}}=\underline{\mathrm{CH}}), 121.9(\mathrm{O}-\underline{\mathrm{C}}-\mathrm{C}=\mathrm{O}), 110.2\left(\mathrm{CH}_{3}-\right.$ $\left.\mathrm{C}-\mathrm{O}-\mathrm{CH}_{2}\right), 74.7(\mathrm{O}-\underline{\mathrm{CH}}-\mathrm{CH}-\mathrm{C}-\mathrm{O}), 74.2(\mathrm{O}-\mathrm{CH}-\underline{\mathrm{CH}}-\mathrm{C}-$ $\mathrm{O})$, 72.6, $72.3\left(\mathrm{C}-\mathrm{O}-\underline{\mathrm{CH}}_{2}-\mathrm{CH}_{2}\right), 65.3\left(\mathrm{O}-\mathrm{CH}_{2}-\mathrm{CH}-\mathrm{O}\right), 32.6$ $\left(\mathrm{CH}=\mathrm{CH}-\mathrm{CH}_{2}-\right)$, 29.8, 29.5, 29.2, 29.1 (backbone, $-\mathrm{CH}_{2}-$ ), 25.9, $25.6\left(\mathrm{CH}_{3}-\right)$.

Hydrogenation of Polymer 5. Polymer $4(\sim 0.53 \mathrm{~g})$ was dissolved in 3-4 mL of THF and charged into a flame-dried $25 \mathrm{~mL}$ Schlenk flask with stir bar in it. After two cycles nitrogen-vacuum catalyst palladium on charcoal $(10 \mathrm{~mol} \%)$ was added under a nitrogen atmosphere, and vacuum-nitrogen cleaning was repeated to remove the remaining air. Under vacuum conditions, a balloon with hydrogen was connected. It was stirred at room temperature for 3 days. To purify the product, it was filtered through a Celite 503 using excess of THF, and then the solvent was removed under reduced pressure. A black solid polymer was obtained after removal of the solvents.

Hydrolysis of Polymer 6. Polymer $5(0.51 \mathrm{~g})$ was dissolved in 25 $\mathrm{mL}$ of THF; then $5 \mathrm{~mL}$ of $1 \mathrm{M} \mathrm{HCl}$ solution was added, and the reaction mixture was stirred at $40{ }^{\circ} \mathrm{C}$ overnight. Solvents were evaporated under reduced pressure, and then the crude product was dissolved in a minimal amount of THF and precipitated in methanol. A light-brown solid polymer, soluble in THF and DMSO, was obtained after drying. ${ }^{1} \mathrm{H}$ NMR (d-THF, $\left.\delta\right): 4.59(\mathrm{~s}, 1 \mathrm{H}$, $\mathrm{HOCH}_{2} \mathrm{CHCHO}$ ), $4.31\left(\mathrm{~m}, 2 \mathrm{H}, \mathrm{OCH}_{2} \mathrm{CH}_{2} \mathrm{CH}_{2}\right), 3.97-3.88(\mathrm{~m}$, $\left.2 \mathrm{H}, \mathrm{HOCH} \underline{H}_{2} \mathrm{CHCHO}\right), 3.60\left(\mathrm{~m}, 1 \mathrm{H}, \mathrm{HOCH}_{2} \mathrm{CHCHO}\right), 1.56(\mathrm{~m}$, $4 \mathrm{H}, \mathrm{OCH}_{2} \mathrm{CH}_{2} \mathrm{CH}_{2}$ ), 1.19 (br s, $\left.24 \mathrm{H}\right) \cdot{ }^{13} \mathrm{C}$ NMR (d-THF, $\delta$ ): 168.8 $(\mathrm{O}-\mathrm{C}-\underline{\mathrm{C}}=\mathrm{O}), 156.8(\mathrm{HO}-\mathrm{CH}-\mathrm{CH}-\underline{\mathrm{C}}-\mathrm{O}), 121.9(\mathrm{O}-\underline{\mathrm{C}}-\mathrm{C}=$ O), $75.0(\mathrm{HO}-\mathrm{CH}-\underline{\mathrm{C}} \mathrm{H}-\mathrm{C}-\mathrm{O}), 72.0,71.8\left(\mathrm{C}-\mathrm{O}-\mathrm{CH}_{2}-\mathrm{CH}_{2}\right)$, $70.1(\mathrm{HO}-\underline{\mathrm{C}} \mathrm{H}-\mathrm{CH}-\mathrm{C}-\mathrm{O}), 62.8\left(\mathrm{HO}-\mathrm{CH}_{2}-\mathrm{CH}-\mathrm{O}\right), 30.0,29.7$, 26.2, 25.9, 25.7 (backbone, $-\mathrm{CH}_{2}-$ ).

Fluorescent Labeling. Polymer $6(22.73 \mathrm{mg})$ was dissolved in 5 $\mathrm{mL}$ of THF; $0.06 \mathrm{mg}$ of 4-(dimethylamino)pyridine (DMAP) and dye (1.2327 mg of Cy-3 or $1.2978 \mathrm{mg}$ of Cy-5) were added and dissolved in $0.3 \mathrm{~mL}$ of dichloromethane. Then the mixture was cooled to $0{ }^{\circ} \mathrm{C}$; afterward, $1.0316 \mathrm{mg}$ of dicyclohexylcarbodiimide (DCC) was added. The mixture was stirred at room temperature over 2 days. Excess of water with two drops of hydrochloric acid was added. For the purification, the product was washed twice with deionized water and precipitated by a centrifuge. Colored polymer crystals, soluble in THF and DMSO, were obtained after drying.

\section{RESULTS AND DISCUSSION}

Monomer and Polymer Synthesis (Scheme 1). For the preparation of the ADMET monomer $\mathbf{3}$, ascorbic acid $\mathbf{1}$ was protected first as acetonide. Vitamin $\mathrm{C}$ was dissolved in an excess of acetone containing catalytic amounts of acetyl chloride. The acetonide 2 crystallized directly from the reaction in yields of $80-85 \%$. The speed of this reaction depends on the temperature: at $0{ }^{\circ} \mathrm{C}$ even after several hours stirring no changes were detected (Figure S1); after $4 \mathrm{~h}$ at room temperature the appearance of peaks at 4.06, 4.20, 4.49, and $4.81 \mathrm{ppm}$ in the ${ }^{1} \mathrm{H}$ NMR spectrum is indicative of acetonide. After stirring the reaction mixture overnight at 40 ${ }^{\circ} \mathrm{C}$, we obtained the almost fully protected form of L-ascorbic acid.

The monomer 3 for ADMET polymerization was prepared according to Scheme 1 in a mixture of DMSO/THF with excess of 11-bromo-1-undecene. After column chromatography the structure of 3 was confirmed by NMR spectroscopy and mass spectrometry (Figures S2 and S3) (peak with mass 521.0 originated for the disubstituted acetonide form of L-ascorbic acid). The terminal olefin protons were detected at 4.9 and 5.7 ppm and the terminal olefin carbon signal at 139.2 and 114.2 ppm from ${ }^{1} \mathrm{H}$ and ${ }^{13} \mathrm{C}$ NMR spectra, respectively, indicating that the alkylation reaction was successful (Figure S4).

Polymerization of 3 was conducted in the bulk in the presence of $1 \%$ of Grubbs first-generation catalyst. Instead of terminal double bonds, multiplets at 4.9 and $5.7 \mathrm{ppm}$, a new internal double bond multiplet at $5.30 \mathrm{ppm}$ was detected in ${ }^{1} \mathrm{H}$ NMR spectra after ADMET polycondensation. Internal double bonds in 4 were hydrogenated in the presence of palladium hydroxide on activated charcoal. The structure of successfully hydrogenated polymer $\mathbf{5}$ was confirmed by NMR spectroscopy (Figures S3 and S4).

Comparison of the ${ }^{13} \mathrm{C}$ NMR spectra of monomer before polymerization and polymer after hydrogenation (Figure S4) shows signals at $139.1,114.12$, and $33.8 \mathrm{ppm}$ (1, k, and m peaks in ${ }^{13} \mathrm{C}$ NMR spectra, respectively), which proves that the terminal double bonds in the monomer disappeared after polymerization, changed to internal olefins, and vanished from the spectra after hydrogenation.

The hydrolysis of the ketal groups in polymer $\mathbf{5}$ was achieved in THF by the addition of $\mathrm{HCl}$ solution. The structure of deprotected poly(vitamin C) 6 with functional $\mathrm{OH}$ groups was confirmed by ${ }^{1} \mathrm{H}$ and ${ }^{13} \mathrm{C}$ NMR spectroscopy. In the ${ }^{13} \mathrm{C}$ NMR spectra (Figure S4), the peak at $110.2 \mathrm{ppm}$ was completely removed; in ${ }^{1} \mathrm{H}$ NMR spectra the methine and methylene protons next to hydroxyl groups at 3.6-4.6 ppm have shifted to positions, corresponding to the expected 
Table 1. Molecular Weights and Thermal Properties of the Unsaturated and the Deprotected and Hydrogenated Polymer

$\begin{array}{cccccccc}\text { polymer } & M_{\mathrm{n}}{ }^{a}\left(\mathrm{~g} \mathrm{~mol}^{-1}\right) & M_{\mathrm{w}}{ }^{a}\left(\mathrm{~g} \mathrm{~mol}^{-1}\right) & \Xi^{a} & T_{\mathrm{m}}{ }^{b}\left({ }^{\circ} \mathrm{C}\right) & T_{\mathrm{c}}{ }^{b}\left({ }^{\circ} \mathrm{C}\right) & \Delta H_{\mathrm{m}}{ }^{b}\left(\mathrm{~J} \mathrm{~g}^{-1}\right) & \Delta H_{\mathrm{c}}{ }^{b}\left(\mathrm{~J} \mathrm{~g}^{-1}\right) \\ \mathbf{4} & 18300 & 35800 & 2.0 & 29.3 & 9.5 & -37.0 & 30.6 \\ 6 & 12050 & 19900 & 1.7 & 99.4 & 90.6 & -42.9 & 45.6\end{array}$

${ }^{a}$ Determined by SEC in THF vs polysterene standatd. ${ }^{b}$ Determined by DSC.
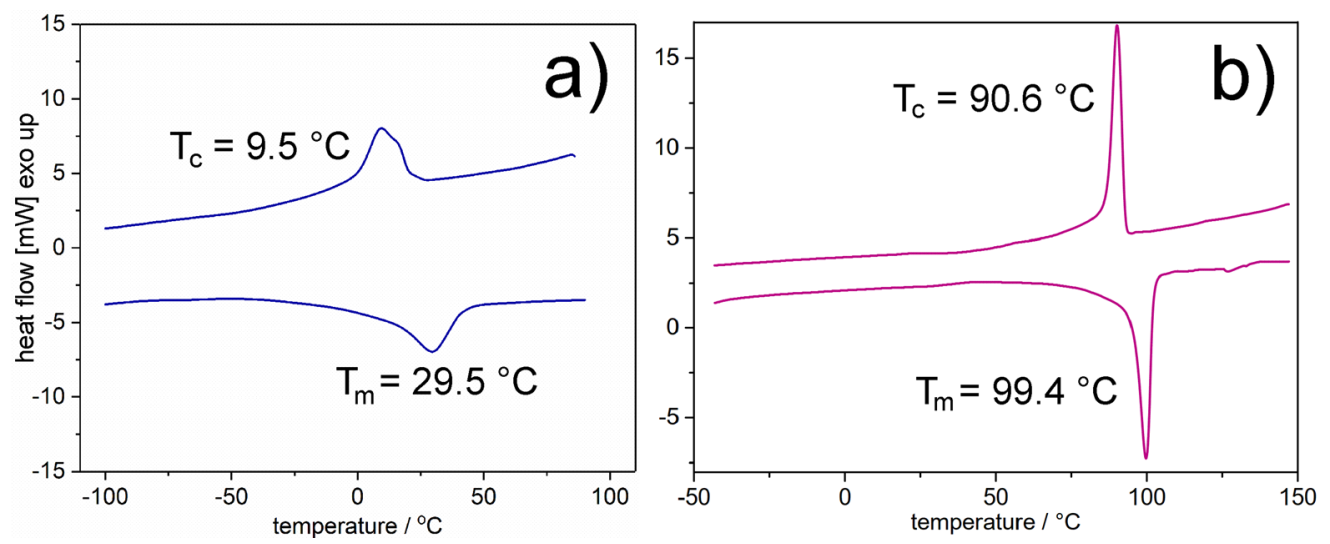

Figure 1. DSC thermograms of polymers 4 and 6. The hydrogenation of polymer 4 to polymer $\mathbf{6}$ results in a significant shift of crystallization and melting temperature of $\sim 70^{\circ} \mathrm{C}$. This has to be attributed to the elimination of the central double bond which acts as an additional defect for the crystallization.

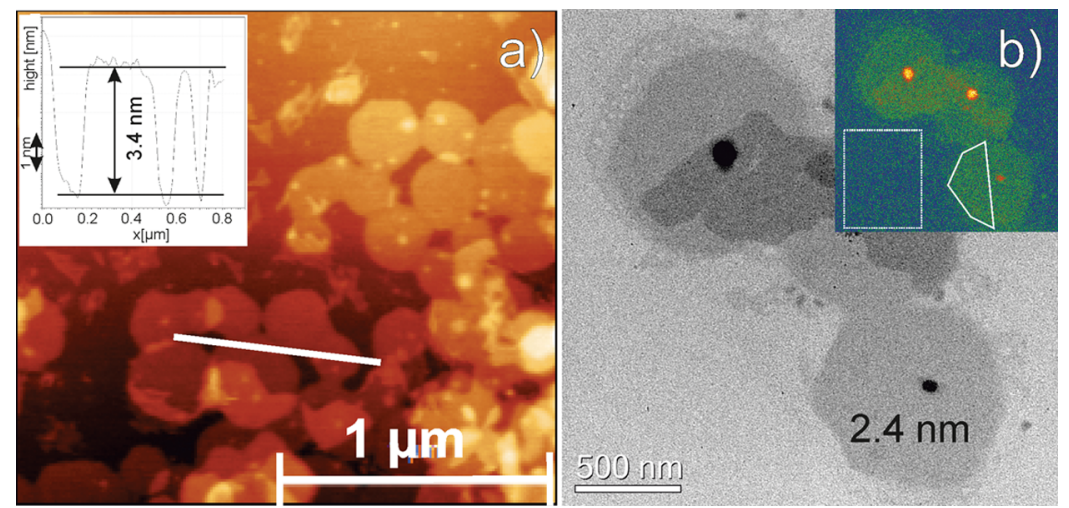

Figure 2. Thickness of solution grown single crystals of polymer 6. (a) AFM topography yields a lamellar thickness of $3.4 \mathrm{~nm}$ (inset: height profile along the indicated line). (b) EFTEM micrograph and thickness map (inset) yielding a lamellar thickness of $2.4 \mathrm{~nm}$. The annotated areas indicate the positions used for the thickness measurement of the carbon substrate and the single crystal.

structure of product 6 , which is similar to initial L-ascorbic acid before modifications. The ${ }^{13} \mathrm{C}$ NMR spectra of polymer 6 reveal vitamin $\mathrm{C}$ ring peaks at 121.0, 155.4, and $168.2 \mathrm{ppm}$ (Figure S4, peaks a, b, and c), which confirm that hydrogenation conditions are mild enough and the eneone within the vitamin $\mathrm{C}$ moiety survived the process.

By comparing GPC elugrams of polymers 4 and 6 , we observed a slight shift to a lower molecular weight region since the removal of the ketal group causes the smaller hydrodynamic volume (Figure S5).

The unsaturated polymer 4 synthesized in this study was obtained as a highly viscous, sticky material, while the hydrogenated polymer 5 and its deprotected form 6 were solids.

Solid-State Characterization. Table 1 summarizes the thermal and molecular properties of polymers 4 and 6 synthesized in this study. Both the non-hydrogenated and the hydrogenated polymers can crystallize, as shown by the DSC thermograms in Figure 1. The hydrogenation of 4 to 6 leads to a shift of the main melting temperature $T_{\mathrm{m}}$ from 29 to $99^{\circ} \mathrm{C}$ and an increase in the melting enthalpy from ca. -37 to $-43 \mathrm{~J} \mathrm{~g}^{-1}$. Correspondingly, the crystallization temperature $T_{\mathrm{c}}$ increases from 9 to $91{ }^{\circ} \mathrm{C}$ upon hydrogenation. The glass transition temperature $T_{\mathrm{g}}$ for both polymers could not be explicitly read from the DSC thermograms. The melting and crystallization temperatures of polymer $\mathbf{6}$ are remarkably high, especially considering that the molecular chain has a defect concentration of $1 / 20$. Common PE shows a melting temperatures around $130{ }^{\circ} \mathrm{C}$ with a molecular defect concentration well below $1 \% .{ }^{19}$ Precision polymers with pure aliphatic pendant groups placed every $20 \mathrm{CH}_{2}$ units along the chain show melting temperatures ranging from $63{ }^{\circ} \mathrm{C}$ for a methyl branch down to $\sim 12{ }^{\circ} \mathrm{C}$ for larger branches like propyl. ${ }^{20}$ For similar polymers containing in-chain aromatic or other bulky defects remarkably higher melting temperatures have been observed as well. ${ }^{21-23}$ The vitamin $\mathrm{C}$ substituted polymer 6 is similar to the arylene ether polymer with the defect group substituted in the ortho-position reported by Song et al., which exhibited a melting temperature of 81.7 ${ }^{\circ} \mathrm{C} .{ }^{24}$ 

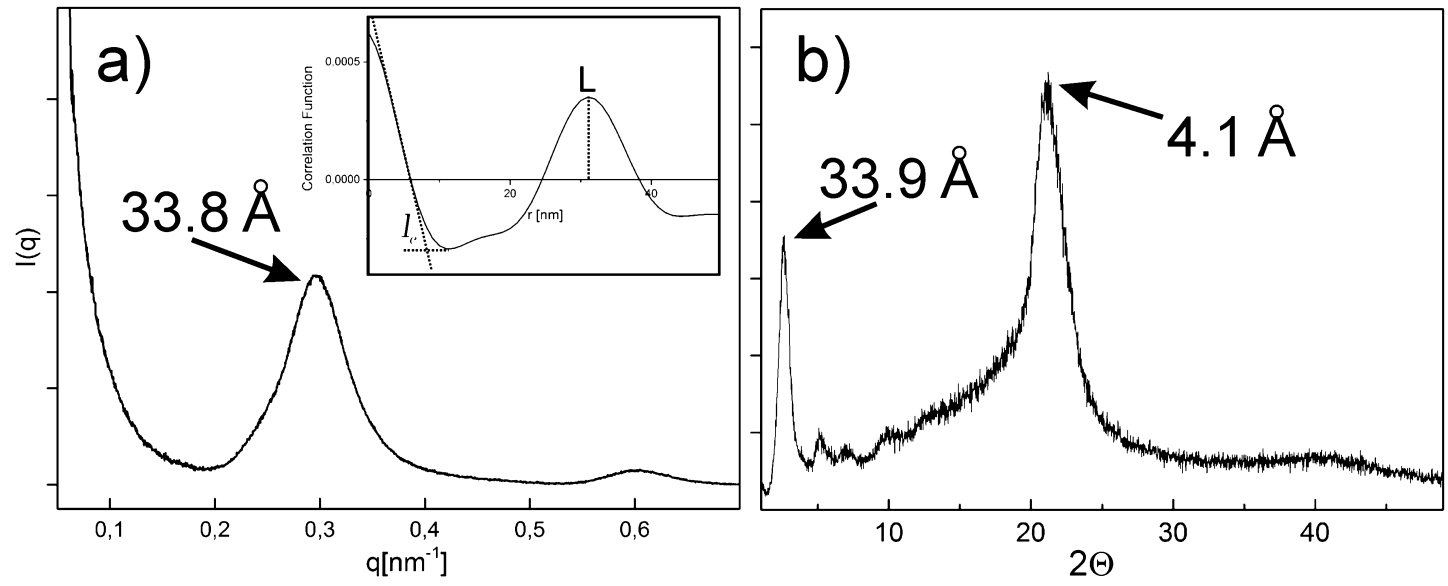

Figure 3. (a) SAXS data with the corresponding correlation function (inset) and (b) WAXS measurements of polymer 6.
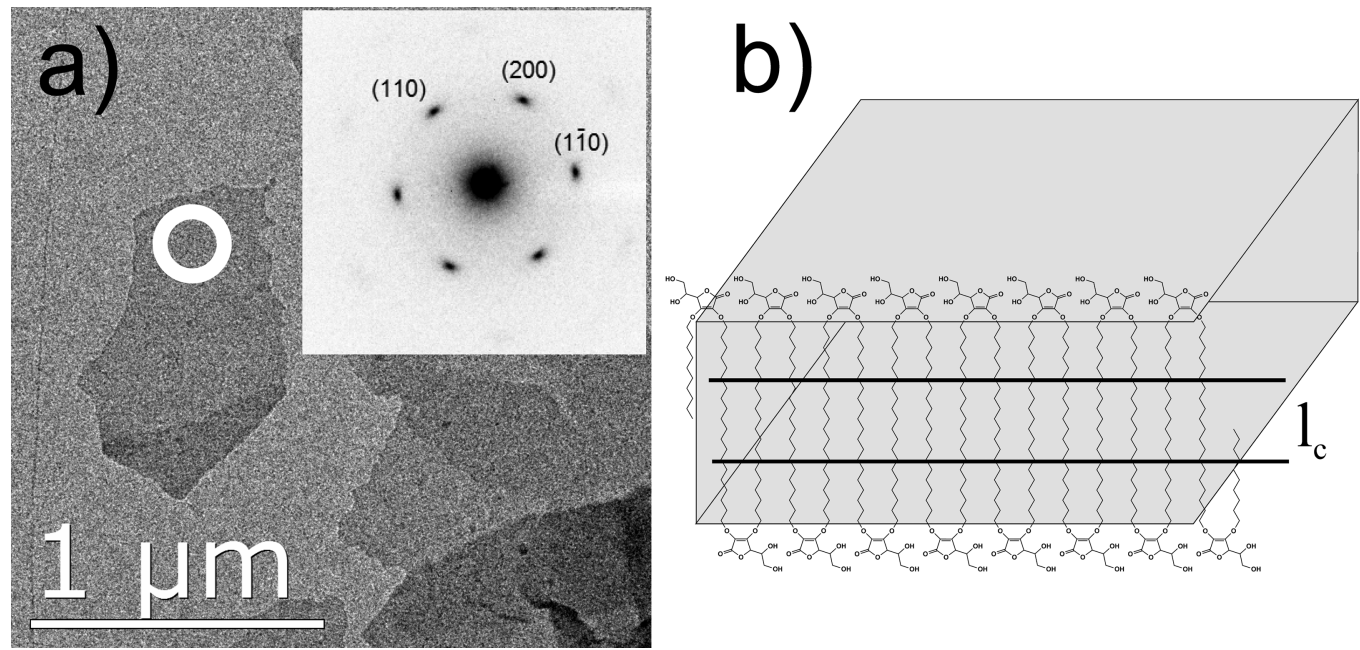

Figure 4. (a) TEM bright-field micrograph and selected area electron diffraction pattern (inset) of solution grown single crystal of polymer 6 from ethyl acetate solution. The diffraction spots reveal a nearly perfect quasi-hexagonal crystal structure with a lattice distance of $4.16 \AA \AA$ for (110) and $4.10 \AA$ for (200). Assuming an orthorhombic crystal lattice, the lattice constants for polymer 6 are $a=8.2 \AA$ and $b=4.8 \AA$. The schematic molecular model for the lamellar crystal is shown in (b). When assuming an adjacent reentry, the vitamin $\mathrm{C}$ groups are expelled from the crystal to the lamellar basal planes. The perfectly crystalline layer makes up only a small part of the entire lamella, as indicated by $l_{c}$.

For crystallization and the formation of a crystal lattice, the vitamin $\mathrm{C}$ group represents a bulky defect that cannot be incorporated into the crystal lattice and is therefore expelled to the basal surface of the crystal. However, the ortho-substituted vitamin $\mathrm{C}$ groups promote an adjacent reentry of the $\mathrm{PE}$ chains at the crystal surfaces. Consequently, the lamellar thickness is limited by the precise alkyl spacing of $20 \mathrm{CH}_{2}$ units, which amounts to a total length of $20 \times 0.127 \mathrm{~nm}=2.5 \mathrm{~nm}$ for $\mathrm{C}_{20}$ alkyl chains in the all-trans configuration. Figure 2 shows measurements of solution grown single crystals of polymer 6 by AFM and EFTEM. From AFM topography we extracted a crystal thickness of $\sim 3.4 \mathrm{~nm}$, which corresponds to a distance given by $20 \mathrm{CH}_{2}$ units and 2 vitamin $\mathrm{C}$ molecules situated at the top and bottom of the crystal. EFTEM yields a thickness of $2.4 \mathrm{~nm}$. The latter is very close to the expected lamellar thickness formed by $20 \mathrm{CH}_{2}$ units in the all-trans configuration. Possibly the electron beam damage during the TEM measurement leads to a loss of the vitamin $\mathrm{C}$ molecules, and only the polymer crystal bulk remains.

The above-mentioned thicknesses have been measured on solution grown single crystals whereas the thermal characterization was done by using melt crystallized samples.
Accordingly, X-ray scattering measurements of annealed polymer $\mathbf{6}$ have been performed to better correlate the thermal data to the underlying crystal structure. Prior to the X-ray measurements, the polymer was annealed at $80{ }^{\circ} \mathrm{C}$ for $5 \mathrm{~h}$. Figure 3 shows the data obtained by small- and wide-angle Xray scattering.

At small angles, a peak corresponding to a long period of 33.9 $\AA$ is found in the SAXS and WAXS patterns. Moreover, in the WAXS pattern (Figure 3b) a broad peak with 4.1 A lattice plane distance represents in-plane reflections of the PE crystal. $\mathrm{PE}$ crystallizes in an orthorhombic unit cell which gives rise to distinct (110) and (200) Bragg reflections at $2 \theta=21.7^{\circ}$ and $24^{\circ}$, respectively. When the polymer crystallizes in a pseudohexagonal crystal structure, the (110) and the (200) peaks coincide, yielding one peak around $2 \theta \approx 21^{\circ} .25$ Furthermore, using eq 2, we determined the crystallinity of polymer 6 to be $X_{\mathrm{vol}}=27 \%$ from the WAXS measurement.

The SAXS pattern shows a dominant peak at a long spacing period of $33.8 \AA\left(q=0.29 \mathrm{~nm}^{-1}\right)$. A weaker, second-order peak is observed at $q=0.59 \mathrm{~nm}^{-1}$. The long spacing period of 33.8 $\AA$ is comparable to the length of $25.4 \AA$ for an all-trans C20 alkyl chain plus the size of two vitamin $\mathrm{C}$ groups as measured 

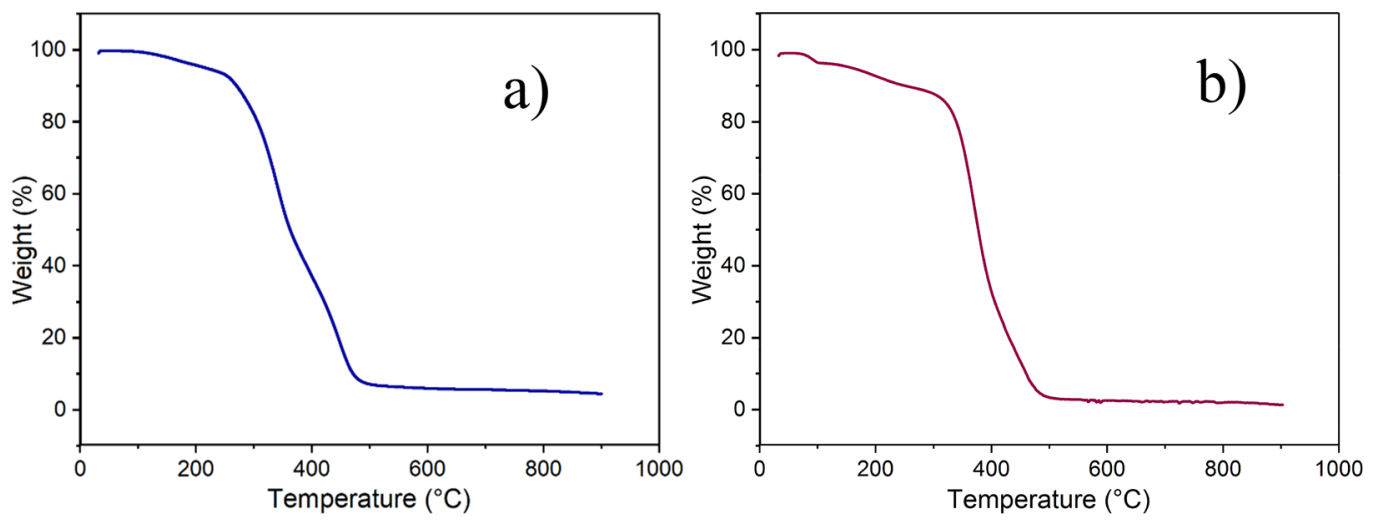

Figure 5. TGA thermograms of (a) the unsaturated polymer 4 and (b) the saturated polymer 6 . There is no significant influence of the hydrogenation on the thermal decomposition characteristics of both polymers.

by AFM. Albeit weak, the clear presence of the second-order peak indicates that the interface between the amorphous and crystalline region is rather sharp. Apparently, the equidistant spacing between the vitamin $\mathrm{C}$ defects in the $\mathrm{PE}$ main chain significantly reduce fluctuations of the lamella periodicity, commonly suppressing the second-order signal. Using eq 4 in combination with the crystallinity obtained from WAXS, we obtained a lamellar crystal thickness $l_{c}=8 \AA$. The pair correlation function extracted from the SAXS data (inset in Figure 3a) shows similar results. According to this, the long period is $L=31.0 \AA$, and the layer thicknesses are 23 and $8 \AA$. As already extracted from the crystallinity measurement, the 8 Å periodicity has to be attributed to the "neat" crystal thickness $l_{\mathcal{c}}$, whereas the $23 \AA$ periodicity is more likely the thickness of the amorphous layer. However, the shape of the resulting correlation function is not ideal, and therefore these results should be treated with some caution. In conclusion, these data from the melt-grown polymer 6 indicate that in between two defects only a few $\mathrm{CH}_{2}$ groups seem to crystallize. Hence, together with the vitamin $\mathrm{C}$ groups a significant fraction of them are excluded from PE crystal lamella and form the amorphous phase. Because of ortho-substitution and the steric effect of vitamin $\mathrm{C}$ defect groups, they cannot be included into the crystal phase, which prevents formation of thick lamellae.

Complementary to the WAXS pattern measured on a meltcrystallized sample, the crystal structure of the lamellar crystals was also determined by electron diffraction of solution grown single crystals (Figure 4a). The SAED diffraction pattern shows a nearly perfect hexagonal structure, with an orthorhombic (110) lattice plane of 4.16 and $4.10 \AA$ for the (200). This results in the orthorhombic lattice constants of $a=$ $8.2 \AA$ and $b=4.8 \AA$. With $a / b=1.71$ the ratio is close to the theoretical value of 1.73 for a hexagonal structure. The lattice constant in the $c$-direction cannot be determined from this measurement. As already observed for other similar PE crystal systems with random incorporation of molecular defects, the crystal lattice inflates preferably in the a-direction of the orthorhombic unit cell. ${ }^{26}$ Combining all the structural data we have achieved, we can propose a structural model of the vitamin $\mathrm{C}$ polymer crystal. The distortion of the vitamin $\mathrm{C}$ groups on the crystal surface is so massive that a crystalline structure is only formed over a thickness of $8 \AA$ in the interior of the lamellae. This refers to a perfect crystal thickness of only three all-trans $\mathrm{CH}_{2}-\mathrm{CH}_{2}$ units. Adjacent, the reorganization with regards to the basally located vitamin $\mathrm{C}$ groups takes place in a $11.5 \AA$ layer on both sides of the crystal. Finally, the vitamin $\mathrm{C}$ group is sitting on the fold surface of the crystal (Figure 4b).

With such a small thickness of the perfect crystalline region, one should expect a much lower melting temperature for the hydrogenated polymer (polymer 6) according to the GibbsThomson equation. ${ }^{27}$ However, a relatively high melting temperature in the range of $90{ }^{\circ} \mathrm{C}$ is observed. Comparatively similarly high melting temperatures with the same molecular defect density ( $20 \mathrm{CH}_{2}$ groups between the functional groups) were also observed for hydroxyl ${ }^{28}$ and ester functions. ${ }^{29-31}$ It can be assumed that the high melting point is due to the interaction of the functional groups on the basal surface of the lamellar crystals. ${ }^{32}$

Decomposition and Degradation. The thermal stabilities of polymers 4 and 6 proved to be very similar and were evaluated by thermogravimetry under a nitrogen atmosphere with a heating rate of $10 \mathrm{~K} \mathrm{~min}^{-1}$. The onset of the main decomposition was detected at ca. $300{ }^{\circ} \mathrm{C}$ and reaches its maximum weight loss at $500{ }^{\circ} \mathrm{C}$ (Figure 5). This main thermal decomposition profile is comparable to the TGA of PE. ${ }^{33}$

Slight mass loss was observed for both samples at temperatures below $300{ }^{\circ} \mathrm{C}$, which might be attributed to the release of water. As the melting temperature of the final polymer 6 is well below the onset temperature, it can be processed like a Thermoplast without chemical alteration.

Accordingly, this polymer could be a promising material for biomedical applications because, on the one hand, it already offers a bioactive component due to the built-in vitamin $\mathrm{C}$ group and, on the other hand, it should have the biocompatible properties of PE. For this reason, we have investigated the degradation and antioxidative properties as well as the biocompatibility of the polymer.

Hydrolytic Degradation. The accelerated hydrolysis of the vitamin C-containing polymer was performed in acidic and basic conditions. Under basic conditions, degradation of the polymer backbone was observed and proven by GPC (Figure S8) and NMR (Figure S6) measurements. Comparison of the ${ }^{1} \mathrm{H}$ NMR spectra of polymer under basic conditions before after degradation reveals the L-ascorbic acid ring signals at 3.8$4.7 \mathrm{ppm}$, which vanished from the spectra after degradation to confirm the success of the process.

To assess degradation kinetics, the polymer was treated with different amounts of $\mathrm{NaOH}$. Even in the experiment with the mildest condition (sample 4 in Table 2), degradation takes place (Figure 6). Moreover, it is remarkable that the polymer can also be degraded in its crystal state (sample 1 in Table 2). 
Table 2. Degradation of Polymer 6 in the Presence of $\mathrm{NaOH}$ under Different Conditions: in Polymer Solution (Samples 2-4) and in Crystal State (Sample 1)

\begin{tabular}{cccccc} 
sample $N$ & $\begin{array}{c}\text { polymer } \\
(\mathrm{mg})\end{array}$ & $\begin{array}{c}\mathrm{NaOH} \\
(\mathrm{mg})\end{array}$ & $\begin{array}{c}\mathrm{THF} \\
(\mathrm{mL})\end{array}$ & $\begin{array}{l}\mathrm{H}_{2} \mathrm{O} \\
(\mathrm{mL})\end{array}$ & $\begin{array}{c}\text { time } \\
(\mathrm{h})\end{array}$ \\
\hline 1 & 10.0 & 4 & & 2 & 10 \\
2 & 5.0 & 4 & 0.5 & 0.05 & 0.5 \\
3 & 5.0 & 2 & 0.5 & 0.05 & 0.5 \\
4 & 5.0 & 0.4 & 0.5 & 0.06 & 0.5 \\
\hline
\end{tabular}

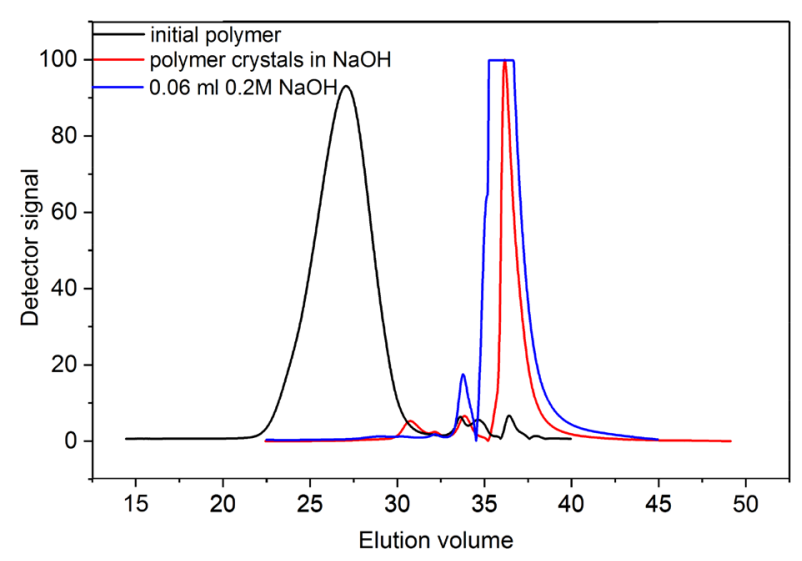

Figure 6. GPC elugrams of polymer 6 (black) and products of degradation in the presence of sodium hydroxide: polymer crystals in $1 \mathrm{M}$ water solution $\mathrm{NaOH}$ (red) and a mixture of $0.1 \mathrm{mg}$ of polymer solution and $0.06 \mathrm{~mL}$ of $0.2 \mathrm{M} \mathrm{NaOH}$ in $0.5 \mathrm{~mL}$ of THF (blue).

This indicates that in the crystal structure the vitamin $\mathrm{C}$ groups are accessible for degradation attacks and accordingly are placed on the crystal surface rather than in the crystal bulk. Or, in other words, if the size of the defect is small enough to be incorporated in the crystal lattice, the degradation rate of the long-chain polyacetals would decrease with increasing length of the methylene sequences. ${ }^{34}$ That makes it beneficial to aim for polymer structures with big defects, forming functional surfaces which are accessible for degradation or capable for functionalization.

Free Radical Scavenging Properties. The DPPH (2,2diphenyl-1-picrylhydrazyl hydrate) free radical method is an antioxidant assay based on electron transfer that produces a violet solution. This organic nitrogen-centered free radical, stable at room temperature, reduces to its colorless nonradical form while interacting with antioxidants.

The final polymer 6 crystals $(0.5 \mathrm{mg})$ were added to DPPH $\left(0.05 \mathrm{mg} \mathrm{mL}^{-1}\right)$ solution in THF and kept for $30 \mathrm{~min}$ in the dark or heat up for $5 \mathrm{~min}$ with a heat gun.

The color of the mixture of DPPH with free radical scavenger vanishes upon heating with a heat gun after $1 \mathrm{~min}$, while the color of pure DPPH solution stays purple even after 5 min of heating with the heat gun. The same result was observed after keeping the samples in the dark for $30 \mathrm{~min}$. For the sample with DPPH solution no difference in the color was detected, but the solution with addition of final hydrogenated polymer turned slightly yellow (Figure S7). Besides, another quite remarkable observation was made by using the protected monomer. A similar experiment was done using the protected monomer without hydroxyl groups instead. Even in this case the reaction and the color change indicate the free radical scavenging potential. We assume that in this case not only hydroxyl groups, typically responsible for radical scavenging process, but also the one of protons next to the oxygen in the polymer chain act as radical scavenger.

The property that polymer 6 can be used as a radical scavenger makes it interesting to use it as a material for encapsulating sensitive drugs. The first prerequisite for using it in nanomedicine is that the polymer or polymer crystals can be transferred to a stable, aqueous dispersion. The particle size was determined by TEM measurements (Figure 2) on the one hand and by DLS (Figure S9) on the other. The mean crystallite size is $\sim 500 \mathrm{~nm}$ (TEM), and the hydrodynamic radius is $215 \mathrm{~nm}$ (DLS). Furthermore, the polymer should not prove to be toxic and should also be taken up by cells. Hence, for the cell experiments, the solution crystallized polymer 6 crystals were successfully transferred to an aqueous phase to check cell toxicity and cell uptake.

Viability and Cell Uptake. As a potential biological relevant material, we tested the biocompatibility of the polymer by assessing the toxicity of the pure polymer with HeLa cells and $3 \mathrm{~T} 3$ fibroblasts. A good cell viability was obtained even with the highest concentration of $50 \mu \mathrm{g} \mathrm{mL}^{-1}$ tested for both cell lines (Figure 7A). The slight increase of the cell viability for the $3 \mathrm{~T} 3$ cells was not significant. The control experiment was done using DMSO. As expected in the presence of $10 \%$ DMSO, the cells were dying and only about $5-10 \%$ of the cells were alive after $24 \mathrm{~h}$.

To assess the biological importance of the material further, the dye Cy5 cyanine was covalently attached to the polymer
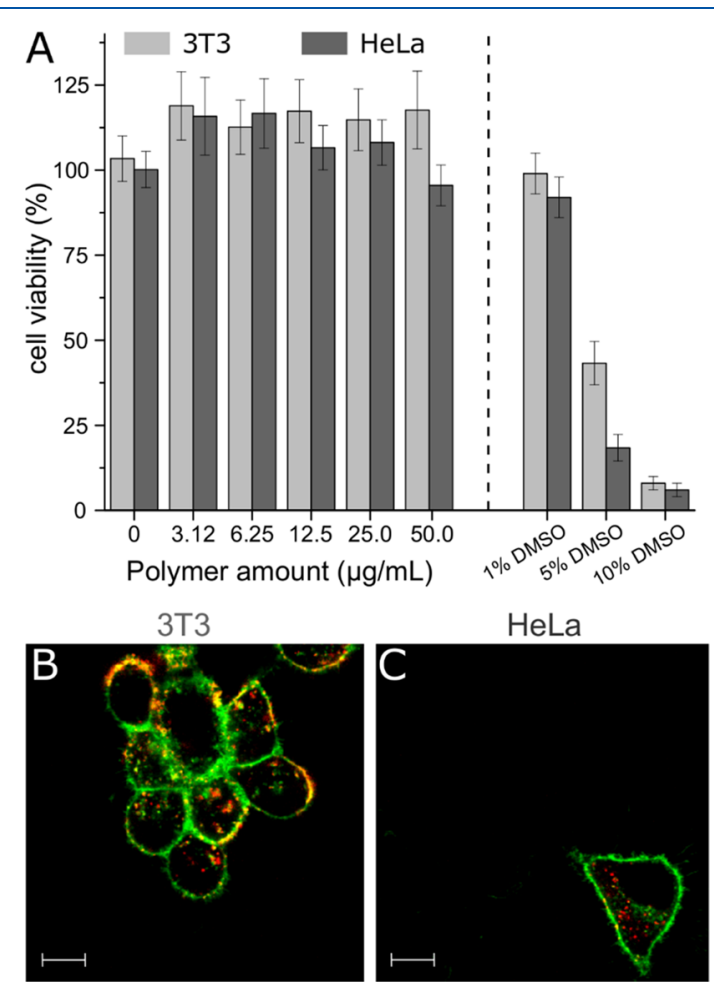

Figure 7. Interaction between vitamin $\mathrm{C}$ polymer and a biological sample. (A) Cytotoxicity of the nanocrystals after $24 \mathrm{~h}$ incubation in cell culture media tested on HeLa and 3T3 cells. DMSO was used as positive control. The error bars represent the standard deviation of the mean of a sextuplet. Cellular uptake of Cy5 nanocrystals (B, C) after $4 \mathrm{~h}$ incubation at $37{ }^{\circ} \mathrm{C}$ was determined by confocal laser microscopy. 3T3 cells (B) and HeLa cells (C) were tested. The cell membrane is represented in green, and the scale bar represents 10 $\mu \mathrm{m}$. 
via esterification reaction. The labeled polymer was then crystallized, and the nanocrystals were incubated to the cells to determine their uptake potential. We observed that depending on the incubation medium, the results are different. In the presence of $10 \%$ FBS in the medium, HeLa cells internalized the nanocrystals to a large extent (Figure $7 \mathrm{C}$ or Figure S12C,D). For 3T3 cells, the nanocrystals remain preferably in the membrane with a limited fraction entering the cell (Figure $7 \mathrm{~B}$ or Figure S11C,D). Based on flow cytometry data (Figure S10), the polymer nanocrystals are favored by $3 \mathrm{~T} 3$ cells with a noticeable increased uptake. In the absence of protein, the nanocrystals tended to aggregate; thus, very limited cell uptake was observed. Finally, in the presence of $10 \%$ human serum, an unfavorable protein layer adsorbed on the nanocrystal surface could explain the low uptake by the cells.

Overall, the polymer interacts with the cells and can be internalized by them. The polymer is not toxic to the cells, making it a promising new material for biomedical applications. However, we have not yet checked for any positive effect of the vitamin $\mathrm{C}$ polymer on biological systems like cells.

\section{CONCLUSION}

This work reports on the synthesis of a polyethylene-like polymer with a vitamin $\mathrm{C}$ group built into the main chain. Because of the ADMET polymerization, the vitamin $\mathrm{C}$ is arranged equidistantly with a distance of $20 \mathrm{CH}_{2}$ groups. This polymer crystallizes in a lamellar morphology. Because of the uniform arrangement of the vitamin $C$ groups, crystal lamellae are formed with a homogeneous thickness of about $2.5 \mathrm{~nm}$, corresponding to their distance in the chain. The vitamin $\mathrm{C}$ groups are expelled from the crystal and are located on the basal surface of the crystals. The melting temperature is $92{ }^{\circ} \mathrm{C}$, and thus the polymer can be processed like a Thermoplast with the usual process methods. Furthermore, the polymer is a suitable candidate for biomedical applications. The bioactive properties, especially the radical scavenging of the built-in vitamin $\mathrm{C}$ group, are transferred to the polymer. We have shown that despite the chemical modification its antioxidant function is retained and that the polymer acts as a radical scavenger. In addition, the polymer is a potential biocompatible material. The polymer is not cytotoxic and is taken up by cells in nanoparticular form via endocytotic pathways. Because of these properties, it is a promising candidate for a drug delivery system to protect sensitive drugs to bring them into the cytoplasm as a medically effective system. The next task will therefore be to investigate the biomedical properties of this vitamin $\mathrm{C}$-containing polymer as a drug carrier system in more detail.

\section{ASSOCIATED CONTENT}

\section{SI Supporting Information}

The Supporting Information is available free of charge at https://pubs.acs.org/doi/10.1021/acs.macromol.0c00086.

NMR and mass spectra, GPC results, and FACS measurements (PDF)

\section{AUTHOR INFORMATION}

\section{Corresponding Author}

Ingo Lieberwirth - Max Planck Institute for Polymer Research, 55128 Mainz, Germany; 이이이.org/0000-0003-1323-

524X; Email: lieberwirth@mpip-mainz.mpg.de

\section{Authors}

Oksana Suraeva - Max Planck Institute for Polymer Research, 55128 Mainz, Germany

Carole Champanhac - Max Planck Institute for Polymer Research, 55128 Mainz, Germany

Volker Mailänder - Max Planck Institute for Polymer Research, 55128 Mainz, Germany; Department of Dermatology, University Medical Center of the Johannes Gutenberg-University Mainz, 55131 Mainz, Germany

Frederik R. Wurm - Max Planck Institute for Polymer Research, 55128 Mainz, Germany; 이이.org/0000-00026955-8489

Henning Weiss - Max Planck Institute for Polymer Research, 55128 Mainz, Germany

Rüdiger Berger - Max Planck Institute for Polymer Research, 55128 Mainz, Germany; 이이이.org/0000-0002-4084-0675

Markus Mezger - Max Planck Institute for Polymer Research, 55128 Mainz, Germany; 이이.org/0000-0001-9049-6983

Katharina Landfester - Max Planck Institute for Polymer Research, 55128 Mainz, Germany; 이이.org/0000-00019591-4638

Complete contact information is available at:

https://pubs.acs.org/10.1021/acs.macromol.0c00086

\section{Notes}

The authors declare no competing financial interest.

\section{ACKNOWLEDGMENTS}

The authors acknowledge support from the "Deutsche Forschungsgemeinschaft" (SFB 1066) and the Max-Planck Society. Our thanks go to Petra Räder and Michael Steiert from the Max Planck Institute for Polymer Research for assistance with the DSC and WAXS measurements. We thank Helma Burg for performing AFM measurements.

\section{REFERENCES}

(1) Ritter, H. Functionalized Polymers: Synthesis and Properties. Beilstein J. Org. Chem. 2010, 6 (May), 1-2.

(2) Schulz, D. N.; Patil, A. O. Functional Polymers: An Overview. ACS Symp. Ser. 1998, 704, 1-14.

(3) Crompton, T. R. Functional Groups in Polymers. In Practical Polymer Analysis; Springer: Boston, MA, 1993; pp 241-255.

(4) Schulz, M. D.; Wagener, K. B. Precision Polymers through ADMET Polymerization. Macromol. Chem. Phys. 2014, 215, 19361945.

(5) Mutlu, H.; de Espinosa, L. M.; Meier, M. A. R. Acyclic Diene Metathesis: A Versatile Tool for the Construction of Defined Polymer Architectures. Chem. Soc. Rev. 2011, 40, 1404-1445.

(6) Trigg, E. B.; Gaines, T. W.; Maréchal, M.; Moed, D. E.; Rannou, P.; Wagener, K. B.; Stevens, M. J.; Winey, K. I. Self-Assembled Highly Ordered Acid Layers in Precisely Sulfonated Polyethylene Produce Efficient Proton Transport. Nat. Mater. 2018, 17 (8), 725-731.

(7) Aitken, B. S.; Buitrago, C. F.; Heffley, J. D.; Lee, M.; Gibson, H. W.; Winey, K. I.; Wagener, K. B. Precision Ionomers: Synthesis and Thermal/Mechanical Characterization. Macromolecules 2012, 45 (2), 681-687.

(8) Mandal, J.; Prasad, S. K.; Rao, D. S. S.; Ramakrishnan, S. Periodically Clickable Polyesters: Study of Intrachain Self- Segregation Induced Folding, Crystallization, and Mesophase Formation. J. Am. Chem. Soc. 2014, 136, 2538-2545.

(9) Haider, T.; Shyshov, O.; Suraeva, O.; Lieberwirth, I.; Von Delius, M.; Wurm, F. R. Long-Chain Polyorthoesters as Degradable Polyethylene Mimics. Macromolecules 2019, 52 (6), 2411-2420. 
(10) Bendich, A.; Machlin, L. J.; Scandurra, O.; Burton, G. W.; Wayner, D. D. M. The Antioxidant Role of Vitamin C. Adv. Free Radical Biol. Med. 1986, 2 (2), 419-444.

(11) Van Der Reest, J.; Gottlieb, E. Anti-Cancer Effects of Vitamin C Revisited. Cell Res. 2016, 26 (3), 269-270.

(12) Capuzzi, G.; Lo Nostro, P.; Kulkarni, K.; Fernandez, J. E. Mixtures of Stearoyl-6-O-Ascorbic Acid and $\alpha$-Tocopherol: A Monolayer Study at the Gas/Water Interface. Langmuir 1996, 12, 3957-3963.

(13) Wang, H. P.; Khariwala, D. U.; Cheung, W.; Chum, S. P.; Hiltner, A.; Baer, E. Characterization of Some New Olefinic Block Copolymers. Macromolecules 2007, 40 (8), 2852-2862.

(14) Data Analysis Software for for Small Angle Scattering Analysis. https://www.Sasview.org.

(15) Egerton, R. Electron Energy-Loss Spectroscopy in the Electron Microscope; Springer: Boston, MA, 2011.

(16) Brand-Williams, W.; Cuvelier, M. E.; Berset, C. Use of a Free Radical Method to Evaluate Antioxidant Activity. Leb. u.-Technol. 1995, 28 (1), 25-30.

(17) Promega. CellTiter 96® Aqueous One Solution Cell Proliferation Assay Protocol, Instruction for Use of Products G3580, G3581 and G3582. [Online Document]. 12.2012 [Zuletzt Aufgerufen Am. 05.09.2017]. Verfügbar Unter: https://www. Promega.de/-/Media/Files/Resources/Pr. 608-277.

(18) Jung, M. E.; Shaw, T. J. Total Synthesis of (R)-Glycerol Acetonide and the Antiepileptic and Hypotensive Drug (-)- $\gamma$-Amino$\beta$-Hydroxybutyric Acid (GABOB): Use of Vitamin C as a Chiral Starting Material. J. Am. Chem. Soc. 1980, 102, 6304-6311.

(19) Wunderlich, B. The Melting of Defect Polymer Crystals. Polymer 1964, 5, 611-624.

(20) Rojas, G.; Inci, B.; Wei, Y.; Wagener, K. B.; Gaines, V. Precision Polyethylene: Changes in Morphology as a Function of Alkyl Branch Size. J. Am. Chem. Soc. 2009, 131, 17376-17386.

(21) Zheng, Y.; Tee, H. T.; Wei, Y.; Wu, X.; Mezger, M.; Yan, S.; Landfester, K.; Wagener, K.; Wurm, F. R.; Lieberwirth, I. Morphology and Thermal Properties of Precision Polymers: The Crystallization of Butyl Branched Polyethylene and Polyphosphoesters. Macromolecules 2016, 49, 1321-1330.

(22) Bauer, K. N.; Tee, H. T.; Lieberwirth, I.; Wurm, F. R. In-Chain Poly(Phosphonate)s via Acyclic Diene Metathesis Polycondensation. Macromolecules 2016, 49, 3761-3768.

(23) Friebel, J.; Ender, C. P.; Mezger, M.; Michels, J.; Wagner, M.; Wagener, K. B.; Weil, T. Synthesis of Precision Poly(1,3Adamantylene Alkylene)s via Acyclic Diene Metathesis Polycondensation. Macromolecules 2019, 52 (12), 4483-4491.

(24) Song, S.; Guo, Y.; Wang, R.; Fu, Z.; Xu, J.; Fan, Z. Synthesis and Crystallization Behavior of Equisequential ADMET Polyethylene Containing Arylene Ether Defects: Remarkable Effects of Substitution Position and Arylene Size. Macromolecules 2016, 49, 6001-6011.

(25) Ruiz de Ballesteros, O.; Auriemma, F.; Guerra, G.; Corradini, P. Molecular Organization in the Pseudo-Hexagonal Crystalline Phase of Ethylene - Propylene Copolymers. Macromolecules 1996, 29, 71417148.

(26) Baita Calleja, F. J.; Gonzalez Ortega, J. C.; Martinez de Salazar, J. Distribution of Chain Defects and Microstructure of Melt Crystallized Polyethylene. Polymer 1978, 19, 1094-1099.

(27) Hoffman, J. D.; Weeks, J. Melting Process and the Equilibrium Melting Temperature of Polychlorotrifluoroethylene. J. Res. Natl. Bur. Stand., Sect. A 1962, 66A, 13.

(28) Valenti, D. J.; Wagener, K. B. Direct Synthesis of Well-Defined Alcohol-Functionalized Polymers via Acyclic Diene Metathesis (ADMET) Polymerization. Macromolecules 1998, 31 (9), 2764-2773.

(29) De Ten Hove, C. L. F.; Penelle, J.; Ivanov, D. A.; Jonas, A. M. Encoding Crystal Microstructure and Chain Folding in the Chemical Structure of Synthetic Polymers. Nat. Mater. 2004, 3 (1), 33-37.

(30) Boz, E.; Wagener, K. B.; Ghosal, A.; Fu, R.; Alamo, R. G. Synthesis and Crystallization of Precision ADMET Polyolefins Containing Halogens. Macromolecules 2006, 39 (13), 4437-4447.
(31) Tasaki, M.; Yamamoto, H.; Yoshioka, T.; Hanesaka, M.; Ninh, T. H.; Tashiro, K.; Jeon, H. J.; Choi, K. B.; Jeong, H. S.; Song, H. H.; et al. Microscopically-Viewed Relationship between the Chain Conformation and Ultimate Young's Modulus of a Series of Arylate Polyesters with Long Methylene Segments. Polymer 2014, 55 (7), 1799-1808.

(32) Santonja-Blasco, L.; Zhang, X.; Alamo, R. G. Crystallization of Precision Ethylene Copolymers. Adv. Polym. Sci. 2015, 276, 133.

(33) Peterson, J. D.; Vyazovkin, S.; Wight, C. A. Kinetics of the Thermal and Thermo-Oxidative Degradation of Polystyrene, Polyethylene and Poly(Propylene). Macromol. Chem. Phys. 2001, 202 (6), $775-784$.

(34) Ortmann, P.; Heckler, I.; Mecking, S. Physical Properties and Hydrolytic Degradability of Polyethylene-like Polyacetals and Polycarbonates. Green Chem. 2014, 16, 1816-1827. 